\title{
ДО ПИТАННЯ РОЗВИТКУ ЕМОЦЙННОГО ІНТЕЛЕКТУ СТАРШОКЛАСНИКІВ ПСИХОЛОГО-ПЕДАГОГІЧНИМИ ЗАСОБАМИ
}

\section{Могиляста Світлана}

\author{
Інститут психології імені Г. С. Костюка НАПН України, Київ, Україна, \\ svitlanamb@ukr.net \\ https://orcid.org/0000-0003-1016-3623
}

У розгляді емоційного інтелекту як невід'ємної частини базових характеристик особистості сьогодні важливою проблемою психологічної та педагогічної науки постає завдання пошуку засобів його розвитку. Мета статті розглянути теоретичні підходи щодо пошуку психолого-педагогічних засобів розвитку емоційного інтелекту й можливості уроку англійської мови як засобу впливу на становлення, функціонування та розвиток емоційного інтелекту старшокласників.

У статті використано теоретичні й емпіричні методи досліджсення 3 проблематики розвитку емоційного інтелекту старшокласників та експериментального впровадження в процес вивчення англійської мови елементів психологічних вправ. Розвиток емоційного інтелекту як інтегрованого конструкту передбачає єдність емоційних і когнітивних процесів у цілісній системі здібностей щодо розуміння, усвідомлення, управління власними емоціями, емоційними станами та розуміння, конструктивного впливу на емоції інших. Розглядаючи процес розвитку емоційного інтелекту в аспекті онтогенетичних змін щодо вмінь розуміти, усвідомлювати й управляти емоціями та цілеспрямовано впливати на розвиток окремих складових частин емоційного інтелекту, простежуємо, що проблема пошуку засобів розвитку емоційного інтелекту старшокласників у процесі навчання та виховання актуалізується як у напрямі форм організації пізнавальної діяльності учасників навчально-виховного процесу, так і інтеграції елементів психологічних вправ у процес вивчення окремо взятого предмету на кшталт англійської мови.

Результати. Як результат, нами представлено теоретичний аналіз концептуальних основ проблеми визначення тезаурусу «засоби розвитку». Запропоновано практичне застосування елементів сугестії в контексті сучасного уроку англійської мови відповідно до тематики ситуативного спілкування, передбаченої Державною програмою вивчення іноземних мов. Розглянуто спектр можливостей психологічних вправ і методів у поєднанні 3 лінгводидактичним контентом та деталізовано в плані сучасного уроку англійської мови.

Висновки. Зроблено узагальнення, яке обгрунтовує необхідність континууму в напрямі створення системи розвитку емоційного інтелекту старшо-

ISSN 2308-3743 (Online), ISSN 2227-1376 (Print)

(C) Могиляста С., 2020. Ця стаття відкритого доступу на умовах CC BY-NC 4.0 
класників психолого-педагогічними засобами в рамках освітнього простору навчального закладу, що на основі детальної теоретичної та методологічної концепції видається перспективним.

Ключові слова: емоційний інтелект, засоби розвитку, мистецтво, старшокласники, урок англійської мови.

Mohilyasta Svitlana. On the Issue of High School Students' Emotional Intelligence Development by Psychology-Pedagogical Means. Purpose. Considering emotional intelligence as an integral part of the individual's basic characteristics, today there is an important problem of psychological and pedagogical science and a main task of searching ways for developing it. The purpose of the article is to consider theoretical approaches in the field of searching psychological and pedagogical means for developing emotional intelligence and the possibilities which English lessons give as ways of high school students' emotional intelligence formation, functioning and development.

Methods. There are theoretical and empirical research methods on the development of high school students' emotional intelligence and experimental implementation into the process of learning English elements of psychological exercises. Considering the process of developing emotional intelligence in terms of ontogenetic changes in the ability to understand and manage emotions and feelings; purposeful influence on the individual components of emotional intelligence development; there is a relevant problem of searching ways to develop high school students'emotional intelligence. Educational process, and the integration of psychological exercises elements into the process of studying a subject such as English.

Results. It is represented a theoretical analysis of the conceptual foundations of the problem determining a thesaurus «means of development». The practical application of the suggestopedia elements into a contemporary lesson of English, in the direction of developing skills recognizing, verbalizing, managing emotions and in accordance with the topics of situational communication provided by the State Program for Teaching Foreign Languages.

Conclusions. The range of psychological exercises possibilities and methods in combination with linguo-didactic content there is partially considered and detailed in terms of a contemporary lesson of English. It is created a generalization, which substantiates the need for a continuum in the direction of creating the system for high school students' emotional intelligence developing by psychological and pedagogical means within the space of the educational institution, basised on detailed theoretical and methodological concept it is considered promising.

Key words: emotional intelligence, means of development, art, high school students, English lesson.

Могилястая Светлана. К вопросу развития эмоционального интеллекта старшеклассников психолого-педагогическими средствами. Цель. Рассматривая эмоциональный интеллект как неотъемлемую часть базовых 
характеристик личности, сегодня важной проблемой психологической и педагогической наук считаем задачу поиска средств его развития. Цель статьи рассмотреть теоретические подходы по поиску психолого-педагогических средств развития эмоционального интеллекта и возможности урока английского языка как средства влияния на становление, функционирование и развитие эмоционального интеллекта старшеклассников.

В статье используются теоретические и эмпирические методы исследования по проблематике развития эмоционального интеллекта старшеклассников и экспериментального внедрения в процесс изучения английского языка элементов психологических упражнений. Рассматривая процесс развития эмоционального интеллекта в аспекте онтогенетических изменений в контексте умений понимать, осознавать и управлять эмоциями и целенаправлено влиять на развитие отдельных составляющих эмоционального интеллекта, проблема поиска средств развития эмоционального интеллекта старшеклассников в процессе обучения и воспитания актуализируется как в направлении форм организации познавательной деятельности участников учебно-воспитательного процесса, так и интеграции элементов психологических упражнений в процесс изучения отдельно взятого предмета английского языка.

Pезультаты. Как результат нами представлен теоретический анализ концептуальных основ проблемы определения тезауруса «средства развития». Предлагается практическое применение элементов суггестии в контексте современного урока английского языка в направлении развития умений распознавать, вербализировать, управлять эмоциями в соответствии с тематикой ситуативного общения, предусмотренной Государственной программой изучения иностранных языков. Частично рассматривается спектр возможностей психологических упражнений и методов в сочетании с лингводидактическим контентом, что детализировано в плане современного урока английского языка.

Bbыводы. Обосновывается необходимость континуума в направлении создания системы развития эмоционального интеллекта старшеклассников психолого-педагогическими средствами в рамках образовательного пространства учебного заведения, что на основе детальной теоретической и методологической концепции считается перспективным.

Ключевые слова: эмоциональный интеллект, средства развития, искусство, старшеклассники, урок английского языка

Вступ. Процес вибору освітньої стратегії навчальними закладами рухається в напрямі актуалізації емоційно-факторного компонента, а розвиток емоційного інтелекту учнів винесено на рівень Державного стандарту освіти та розглядається як базовий, що підтверджує SEE Learning $(\mathrm{CEEH})$ - проєкт, розпочатий Міністерством освіти України в жовтні 2019 р., за консультаційної підтримки одного 3 теоретиків емоційного інтелекту Д. Гоулмана (Гоулман, 2008). 
У «Законі про освіту» України (2017р.) вміння застосовувати емоційний інтелект увійшли до переліку ключових компетенцій, якими мають володіти учні Нової української школи, що означає значущість проблеми формування в школярів не лише уявлень про свої емоції та «емоційні здібності», а й умінь усвідомлювати та застосовувати власні особистісні емоційно-вольові якості, конструктивно керувати своїми емоціями, вибудовуючи успішні відносини $з$ іншими на основі емоційного інтелекту.

Проведений нами пошук й аналіз джерел стосовно сучасного стану проблеми засобів розвитку емоційного інтелекту старшокласників засвідчив, що цей напрям $€$ інноваційним та ще недостатньо вивченим, розробленим у вітчизняній педагогіці й психологічній науці, що зумовлено не тільки відсутністю єдиних підходів до розуміння психолого-педагогічних засобів, а й відсутністю достатньої кількості наукових досліджень щодо інструментарію впливу на розвиток емоційного інтелекту старшокласників у системі загальної середньої освіти.

Досить чітко актуальність розвитку емоційного інтелекту описано I. Андреєвою, яка наголошує на вивченні окремих здібностей емоційного інтелекту в онтогенезі та дослідженні цілеспрямованого впливу на розвиток окремих його показників. Учена пов'язує рівень розвитку емоційного інтелекту молодої людини із самоактуалізацією особистості й відзначає, що емоційний інтелект формується протягом життя та особливо важливим є період підліткового і юнацького віку, коли відбувається становлення особистості (Андреєва, 2011:197).

Є. Носенко та Н. Коврига наголошують на відсутності в педагогіці підходів щодо системи цілеспрямованого формування емоційної розумності в процесі навчання та виховання. Учені вбачають, що в теоретичному аспекті проблема розвитку емоційного інтелекту недостатньо досліджена як зарубіжними, так і вітчизняними науковцями, а отже, нерозв'язаність проблеми в соціальному аспекті може загрожувати людству саморуйнуванням, якщо й надалі триватиме тенденція протиставлення розуму емоціям (Носенко та Коврига, 2003).

На думку В. Зарицької, процес розвитку емоційного інтелекту учнів може бути достатньо ефективним на всіх етапах навчання (Зарицька, 2012), а ефективними засобами його розвитку можна вважати музичне мистецтво (Рибакова, 2015), арт-терапію (Опанасюк, 2015), системний цілеспрямований психолого-педагогічний вплив на особис- 
тість (Березовська, 2006). Водночас І. Лящ наголошує на актуальності розвитку емоційного інтелекту на етапі юнацького віку (Лящ, 2015), що збігається з періодом навчання в старшій школі загальноосвітнього навчального закладу.

Мета статті - теоретичне дослідження проблеми психологопедагогічних засобів розвитку емоційного інтелекту старшокласників $і$ розгляд практичного розвивального потенціалу уроку англійської мови як засобу розвитку складових частин емоційного інтелекту старшокласників. Для досягнення цієї мети поставлено такі завдання: 1) вивчення теоретичних досліджень щодо психолого-педагогічних засобів розвитку емоційного інтелекту старшокласників; 2) розгляд уроку англійської мови як засобу розвитку емоційного інтелекту в напрямі управління власними емоційними станами, вербалізації емоцій, формування навичок рефлексії засобами сугестії.

Методи та процедура дослідження. У процесі дослідження використано такі методи, як теоретичні (узагальнення результатів дослідження з теми проблематики емоційного інтелекту старшокласників та розвивального потенціалу уроку англійської мови); емпіричні (експериментальне впровадження в процес вивчення англійської мови елементів психологічних вправ задля розвитку складових частин емоційного інтелекту старшокласників).

Обговорення результатів. Виходячи 3 постулатів П. Саловея, Дж. Майера, Д. Карузо щодо можливості розвитку емоційного інтелекту в процесі вивчення емоційних знань як різновиду інформації, якою оперує емоційний інтелект (Mayer, Salovey \& Caruso, 2016); досліджень прибічників теорії розвитку емоційного інтелекту Р. Робертса, Дж. Меттьюса, М. Зайднера, Д. Люсіна (Zeinder, Roberts, \& Matthews, 2002), наукових розвідок вітчизняних учених щодо засобів розвитку емоційного інтелекту старшокласників (Березовська, 2006), власних досліджень (Могиляста, 2020), вважаємо доцільним розгляд психолого-педагогічних засобів як ефективного інструменту впливу на розвиток емоційного інтелекту старшокласників.

Підвищений інтерес до емоційного інтелекту особистості свідчить про те, що цей феномен відповідає постулатам життєвої психології, адже дає спектр сформованих наукових уявлень про різноманітність людських здібностей (Carroll, 1993), відповідає поглядам Гарднера на між- і внутрішньоособистісний інтелект та теорії множинного інтелекту (Gardner, 1993). 
Незважаючи на те, що науковці, такі як Л. Кронбах, стверджують, що соціальні та емоційні здібності є складним конструктом із погляду їх операціоналізації й розрізнення з традиційними формами інтелекту та фактично не можливі в контексті розвитку (Cronbach, 1970), усе ж більшість науковців доводить, що можна й варто розвивати емоційний інтелект, а сам цей процес трактується сучасною психологічною наукою переважно у двох аспектах - як вивчення онтогенетичних змін щодо здатностей розуміти, усвідомлювати та управляти емоціями й в аспекті цілеспрямованого впливу на розвиток окремих його сторін (Люсин, 2004).

Водночас отримання та використання навичок у сфері емоційного інтелекту можуть мати імпліцитний і експліцитний характери, про що стверджують Р. Робертс, Дж. Меттьюс, М. Зайднер, Д. Люсін та декларують, що такі навички аналогічні когнітивним і їх отримання й використання особистістю полегшуються за умови наявності високого рівня емоційної компетенції (Робертс, Меттьюс, Зайднер, Люсін; 2011), апелюючи до твердження П. Акермана про те, що імпліцитні навички можна співвіднести з кристалізованим інтелектом, експліцитні - відповідно до знань про емоції (Ackerman, 1996).

3 огляду на концепцію взаємозв'язку як зовнішніх чинників впливу на особистість (навчальне середовище, діяльнісні аспекти), так і внутрішньоособистісних складників (власні емоції та емоційні стани, особистістні характеристики, типи мислення, комунікативний і самомотиваційний потенціали особистості, рівень соціалізації та ассертивність поведінки), беручи за основу раціонально-емоційні, поведінкові принципи виховання й відштовхуючись від наукових досліджень Г. Орме щодо вікових особливостей розвитку емоційного інтелекту особистості, які підвищуються відповідно до отримання життєвого досвіду та значно зростають у період юності й зрілості (Орме, 2003: 22), нами розглянуто психолого-педагогічні засоби розвитку емоційного інтелекту старшокласників як такі, що ефективні щодо впровадження в навчально-виховний процес освітніх закладів із метою розвитку емоційного інтелекту старшокласників.

Ураховуємо те, що період навчання в старших класах є одним із важливих періодів учнівства, адже це період розвитку пізнавальних процесів особистості, коли учні досягають рівня готовності, виконувати всі види розумової роботи, уключаючи найскладніші. Психологічні процеси в цей період виходять на такий етап, що розвиток 
способів отримання пізнань дуже часто випереджає особистісний розвиток старшокласників, завершуючи формування в особистості загальної емоційної спрямованості, основ емоційної культури (Реан, 2002). Водночас період навчання в старших класах характеризується спрямованістю особистості в майбутнє, зосередженістю на професійному самовизначенні, значною стійкістю світоглядних установок, кращому управлінні власними емоційними станами, почуттями, із більш стійкими настроями, аніж у підлітковому віці, що передбачає як самообмеження, так і відмову від фантазій підліткового періоду (Крейдун і Прядко, 2011: 71)

Виходячи 3 двоаспектності розгляду вченими шляхів розвитку емоційного інтелекту як щодо можливостей цілеспрямованого впливу на окремі складові частини моделі емоційного інтелекту, так і щодо онтогенетичних змін у здатності до розуміння й управління емоціями виникає проблема засобів та методів формування базових компонентів емоційного інтелекту старшокласників у процесі навчання. За умови того, що під засобами навчання нового покоління для закладів освіти визначено спеціально створені об'єкти, які формують навчальне середовище, беруть участь у навчальній діяльності, виконуючи при цьому навчальну, виховну й розвивальну функції, сприяють оптимальному поєднанню теоретичних та практичних компонентів знань, приведенню змісту шкільної освіти відповідно до рівня розвитку науки й техніки та суспільства в цілому (Жук, 1997).

Відзначимо, що все ж єдиного погляду на поняття «засоби розвитку», «засоби навчання» не існує. 3 одного боку, науковці пропонують трактування у вузькому розумінні окремо взятого терміна «засіб» як спеціально створених джерел навчальної інформації та «засіб»- інструменти вчителя й учнів в освітньому процесі. 3 іншого боку, існує інтерпретація «засіб розвитку» як засіб виконання діяльності, що дає в нашому випадку старшокласникам можливість отримувати опосередковане та узагальнене пізнання об'єктивної дійсності. Педагогічна література пропонує різні класифікації засобів як за формою організації пізнавальної діяльності учасників навчальновиховного процесу (самостійної й фронтальної), так і за функціями (інформаційні, контролюючі, тренувальні), де є важливо під час їх вибору враховувати поставлені дидактичні завдання та способи реалізаціï, беручи до уваги основні групи засобів: вербальні, навчальнонаочні, технічні (Мойсеюк, 2001). 
Розглядаючи засоби розвитку емоційного інтелекту старшокласників, звернемося до I. Опанасюк, яка доводить результативність упровадження арт-терапії як засобу розвитку емоційного інтелекту старшокласників у контексті образно-символічної специфіки на свідомому й несвідомому рівнях психіки; рефлексивності аксіологічного самопізнання суб'єкта за посередництвом художньо-образної творчості 3 можливістю вільного, розкутого експериментування суб'єкта зі своїми емоційними переживаннями та художньо-образною експресією (Опанасюк, 2015)

О. Просіна, розглядаючи засіб мистецтва як один із найефективніших на шляху розвитку емоційного інтелекту, наголошує, що під цим засобом розуміємо навчання з використанням п'яти методів і прийомів із метою формування вмінь вести спостереження, осмислювати емоційні стани особистості, розвивати навички співпереживання іншим, управління та корегування власних емоцій засобами мистецтва (Просіна, 2018:126)

В. Петрушин наголошує на ефективності розвитку емоційного інтелекту засобами музичного мистецтва та виникненні двобічного зв'язку між розвитком емоційної сфери й рівнем музичної культури молодої людини; позитивного зв'язку емоційного інтелекту з художнім профілем навчання, розглядаючи музичне заняття як інструмент, що дає можливість навчитися розпізнавати та відтворювати різні емоції, які передаються через музичне інтонування, наголошуючи на прийомах використання танцювальних і пластичних рухів у напрямі розвитку емоційного інтелекту (Петрушин, 2016: 68), а Н. Рибакова, аргументуючи ідеями музичної психології та педагогіки мистецтва, убачає можливість розвитку емоційного інтелекту засобами створення емоційно-асоціативних інтерпретацій музики (Рибакова, 2015:152).

Г. Березовська доводить ефективність розвитку емоційного інтелекту старшокласників засобами спеціальної організації навчальновиховного процесу й сценічної діяльності, підсумовуючи, що навчання старшокласників у школі з театральним ухилом уможливлює розвиток андрогенних психологічних характеристик, котрі сприяють підвищенню рівня їхнього емоційного інтелекту (Березовська, 2006:27).

Ми ж поділяємо думку щодо можливості розвитку емоційного інтелекту старшокласників засобами спеціально створених програм, які б були адаптовані відповідно до специфіки навчально-виховного процесу освітнього закладу, та розглядаємо в цьому контексті урок 
англійської мови як такий, що дає простір для ситуативного моделювання, широкого спектра можливостей інтеграції у викладання психологічних вправ і методів у поєднанні з лінгводидактичним контентом.

Планування уроків, які опосередковано впливають на розвиток емоційного інтелекту старшокласників, повинно проводитись особливо ретельно, адже важливе не лише структурування уроку, вибір доцільних психологічних та педагогічних засобів і методів, які сприятимуть реалізації багатовекторного характеру взаємодії учасників освітнього процесу, а й створення відповідної атмосфери на кшталт вибору класної кімнати, навчального матеріалу.

Розглянувши можливість інтегрувати сугестію в напрямі розвитку вмінь розпізнання, вербалізації, управління емоціями, у контексті сучасного уроку англійської мови пропонуємо план уроку англійської мови в 10 класі відповідно до тематики ситуативного спілкування: «Музика» й змістовної лінії навчально-тематичного планування «Музика та старшокласник» де за основу взято зразок плану сучасного уроку англійської мови ТKT Cambridge University Press (Cambridge ESOL, 2020).

\section{План-конспект уроку в 10 класі}

на тему:

\section{«Музика. Управління емоціями засобами музичного мистецтва»}

\section{Компоненти плану уроку:}

Рівень і кількість старшокласників, характеристика класу: 14 Intermediate (B2)

Місце уроку в програмі: старшокласники вже опрацювали тему «Емоційний інтелект» і вступ до теми «Музика».

Основна мета: розширити знання старшокласників щодо ролі музики в управлінні емоціями та емоційними станами.

Допоміжні цілі: практика використання мовного матеріалу з теми «Музика» й «Емоційний інтелект» для опису емоцій та емоційних станів людини; розвиток умінь вербалізації емоцій.

Припущення: старшокласники вміють застосовувати відповідні граматичні структури та вербальні засоби, щоб описувати власні емоції, почуття.

Передбачувана проблема: старшокласники можуть не виявляти бажання виконувати завдання з переліку сугестивних вправ.

Можливе рішення: за потреби запропонувати інші можливості релаксації, ніж вправи сугестії. 
Таблиияя 1

\begin{tabular}{|c|c|c|c|c|}
\hline Чac & Процедура & Поетапні цілі & $\begin{array}{c}\text { Навчальні } \\
\text { матеріали }\end{array}$ & Методи сугестії \\
\hline $\begin{array}{c}5 \\
\text { хвилин }\end{array}$ & $\begin{array}{c}\text { Старшоклас- } \\
\text { ники гово- } \\
\text { рять про му- } \\
\text { зику та емо- } \\
\text { ції, які вона } \\
\text { викликає }\end{array}$ & $\begin{array}{c}\text { Спонукати до } \\
\text { обговорення } \\
\text { музики як дже- } \\
\text { рела позитивних } \\
\text { і негативних } \\
\text { емоцій }\end{array}$ & $\begin{array}{c}\text { Фото, які } \\
\text { демонструють } \\
\text { емоції людини } \\
\text { під час концерту }\end{array}$ & $\begin{array}{c}\text { Налаштування на } \\
\text { роботу засобом } \\
\text { сугестивного } \\
\text { методу «Трюїзм» }\end{array}$ \\
\hline $\begin{array}{c}10 \\
\text { хвилин }\end{array}$ & $\begin{array}{l}\text { 1. Вивчення } \\
\text { лексики: } \\
\text { старшоклас- } \\
\text { ники обира- } \\
\text { ють слова, } \\
\text { щоб описати } \\
\text { свої відчуття } \\
\text { та емоції } \\
\text { щодо музики } \\
\text { 2. Практика } \\
\text { мінідіалогів } \\
\text { (емоції після } \\
\text { відвідування } \\
\text { концерту) }\end{array}$ & $\begin{array}{l}\text { 1. Слухання роз- } \\
\text { слабляючої } \\
\text { музики, налаш- } \\
\text { тування на } \\
\text { вивчення слів. } \\
\text { 2. Учитель під } \\
\text { музику Бетхо- } \\
\text { вена знайомить } \\
\text { із новою } \\
\text { лексикою. }\end{array}$ & $\begin{array}{l}\text { 1. Запис слів } \\
\text { 2. Аудіозапис } \\
\text { музики } \\
\text { Бетховена }\end{array}$ & $\begin{array}{c}\text { Використання } \\
\text { сугестивного } \\
\text { методу } \\
\text { «Контекстуальне } \\
\text { навіювання» }\end{array}$ \\
\hline $\begin{array}{c}10 \\
\text { хвилин }\end{array}$ & $\begin{array}{c}\text { Обмін } \\
\text { інформацією } \\
\text { щодо } \\
\text { різновидів } \\
\text { музичних } \\
\text { творів, які } \\
\text { сприяють } \\
\text { релаксації }\end{array}$ & $\begin{array}{c}\text { Дискусія щодо } \\
\text { музичного } \\
\text { мистецтва як } \\
\text { засобу рефлексіі }\end{array}$ & $\begin{array}{c}\text { Музика Енріко } \\
\text { Моріко }\end{array}$ & \\
\hline $\begin{array}{c}10 \\
\text { хвилин }\end{array}$ & $\begin{array}{c}\text { Презентація } \\
\text { проєктів }\end{array}$ & $\begin{array}{l}\text { 1. Наголосити на } \\
\text { потребі викорис- } \\
\text { тання нової } \\
\text { мовної форми } \\
\text { 2. Увести новий } \\
\text { аспект мови }\end{array}$ & $\begin{array}{l}\text { Зауваження } \\
\text { вчителя/-ки }\end{array}$ & $\begin{array}{c}\text { Використати } \\
\text { метод сугестії } \\
\text { «Метафора» } 3 \\
\text { метою вивчення } \\
\text { нової мовної } \\
\text { форми } \\
\end{array}$ \\
\hline $\begin{array}{c}10 \\
\text { хвилин }\end{array}$ & $\begin{array}{c}\text { Читання } \\
\text { тексту «Music } \\
\text { in my life» }\end{array}$ & $\begin{array}{c}\text { Забезпечити } \\
\text { старшоклас- } \\
\text { никам можли- } \\
\text { вість покращити } \\
\text { навички розу- } \\
\text { міння про- } \\
\text { читаного } \\
\end{array}$ & $\begin{array}{c}\text { Звучить } \\
\text { симфонія } \\
\text { Моцарта № } 40\end{array}$ & $\begin{array}{c}\text { За вибором } \\
\text { учителя }\end{array}$ \\
\hline
\end{tabular}


У педагогічній літературі існує велика кількість лінгводидактичних, психологічних засобів щодо формування базових основ емоційного інтелекту старшокласників, однак перспективним можемо вважати напрям вивчення можливостей розширення спектра психолого-педагогічних засобів на рівні старшої школи загальноосвітнього навчального закладу. Передбачено узагальнення наявних думок стосовно психолого-педагогічних засобів розвитку емоційного інтелекту старшокласників.

Висновки. Отже, незважаючи на суперечливість питання щодо пошуку шляхів i засобів розвитку емоційного інтелекту старшокласників, психолого-педагогічні засоби можуть сприяти ефективному розвитку емоційних знань і навичок, отриманню старшокласниками емоційного досвіду в процесі як спеціального навчання, так і в рамках вивчення окремо взятого предмету, як-от англійська мова, який дає можливість інтеграції психологічних вправ в урок створенням відповідного психологічного середовища.

Перспективи подальших досліджень полягають у проведенні дослідження та пошуку шляхів застосування психологічних і педагогічних засобів формування базових основ емоційного інтелекту в старшокласників.

\section{Література}

1. Андреева, И. Н. (2011). Эмоциональный интеллект как феномен современной психологии: монография. Новополоцьк: ПГУ, 388 с.

2. Березовская, Т. П. (2006). Особенности развития эмоционального интеллекта старшеклассников. Психологический журнал, 2, 24-27.

3. Гоулман, Д. (2008). Эмоциональный интеллект. АСТ Хранитель, 10-43.

4. Жук, Ю. О. (1997). Концепція створення засобів навчання нового покоління для середніх закладів освіти України. Проблеми освіти: наук.-метод. зб. Київ, 10, 207-218.

5. Закон України «Про освіту» (2017). Відомості Верховної Ради (ВВР), $38-39,380$.

6. Зарицька, В.В. (2012) Психологія розвитку емоційного інтелекту у системі професійної підготовки фахівців гуманітарного профілю. «Педагогічна та вікова психологія»: дис. д-ра психол. наук. Запоріжжя, 513 с.

7. Крейдун, Н. П., Прядко, Н. В. (2011) Про деякі психологічні особливості старшокласників. Вісник Харківського наџіонального університету. Серія: Психологія, 959, 70-75.

8. Люсин, Д. В. (2004). Современные представления об эмоциональном интеллекте. Социальный интеллект: теория, измерение, исследования. Москва, $29-36$. 
9. Лящ, О. П. (2015). Детермінанти та можливості формування емоційного інтелекту особистості. Науковий часопис Національного педагогічного університету імені М. П. Драгоманова: зб. наук. ст. М-во освіти і науки України, Нац. пед. ун-т ім. М. П. Драгоманова. Київ: Вид-во НПУ ім. М. П. Драгоманова. Серія 12: Психологічні науки, 1 (46), 210-216.

10. Могиляста, С. М. (2020). Програма розвитку емоційного інтелекту старшокласників психолого-педагогічними засобами. Актуальні проблеми nсихології: зб. наук. праць Ін-ту психології імені Г. С. Костюка НАПН України. T. I. Організачійна психологія. Економічна психологія. Сочіальна психологія. 56, 104-112.

11. МОН України: У 26 школах почався пілот з впровадження програми розвитку м'яких навичок СЕЕН: сочіально-емочійного та етичного навчання. https://mon.gov.ua/ua/news/u-26-shkolah-pochavsya-pilot-z-vprovadzhennya-programi-rozvitku-myakih-navichok-seen-socialno-emocijnogo-ta-etichnogo-navchannya (дата звернення: 03.02.2020).

12. Мойсенюк, Н. С. (2001). Педагогіка: навч. посіб. 3-тє вид., доп. Київ, $608 \mathrm{c}$.

13. Назарова, Т. С., Полат, Е. С. (1998). Средства обучения. Технология создания и использования. Москва: Изд-во УРАО, 204 с.; Педагогика: учеб. пособие (1988)/под ред. Ю. К. Бабанского. Москва: Просвещение, 479 с.

14. Носенко, Е. Л., Коврига, Н. В. (2003). Емоційний інтелект: концептуалізаиія феномену, основні функиії: монографія. Київ: Вища шк., 67-23.

15. Опанасюк, I. В. (2015). Вплив засобів арт-терапії на розвиток емоційного інтелекту старшокласників. Гуманітарний вісник ДВНЗ «Переяслав-Хмельницький державний педагогічний університет імені Григорія Сковороди». Дод. 2 до Вип. 35, I (13): Тем. вип. «Міжнародні Челпанівські психолого-педагогічні читання». Київ: Гнозис, $444 \mathrm{c.}$

16. Орме, Г. (2003). Эмоциональное мышиления как инструмент достижения успеха. Москва: КСП+, 272 с.

17. Петрушин, В. И. (2016). О развитии эмоционального интеллекта в процессе музыкальных занятий. Музыкальное искусство и образование, 2, 68-82.

18. Просіна, О.В. (2018). Розвиток емоційного інтелекту як основа формування професійної компетентності майбутнього вчителя музики. Гірська школа Українських Kарпат, 18, 124-128.

19. Реан, А. А. (2002). Психология человека от рождения до смерти. СанктПетербург: Прайм-Еврознак, 656 с.

20. Рибакова, Н. А. (2015). Развитие эмоционального интеллекта средствами музыки. Психология и психотехника, 2 (77), 150-158 с.

21. Робертс, Р. Д., Меттьюс, Дж., Зайднер, М., Люсін, Д. В. (2011). Эмоииональный интеллект: проблемы теории, измерения и применения на практике. URL: https://psy-journal.hse.ru/data/2011/04/28/1210633238/3-26.pdf

22. Ackerman, P. L. (1996). A theory of adult intellectual development. Process, personality, interests, and knowledge, 22, 227-257. 
23. Carroll, J. B. (1993). Human cognitive abilities: A survey of factor-analytic studies. New York: Cambridge University Press.

24. Gardner, H. (1993). Multiple intelligences: the theory in practice. New York: Basic Books, 304 p.

25. Cronbach, L. J. (1970). The essentials of psychological testing. 3rd ed. New York: Harper \& Row.

26. Mayer, J. D., Salovey, P., Caruso, D. R. (2016). The ability model of emotional intelligence: principles and updates. Emotion Review, 8(4), 290-300. URL: http://dx.doi.org/10.1177/ 1754073916639667

27. The TKT Course M1,2 and 3" (2020). Cambridge ESOL.

28. Zeinder, M., Roberts, R. D., \& Matthews,G. (2002). Can emotional intelligence (EI) be schooled? A critical review. Educational Psychologist, 37, 215231.

\section{References}

1. Andreeva, Y. N. (2011). Emotsyonalnyi yntellekt kak fenomen sovremennoi psykholohyy [Emotional intelligence as a phenomenon of modern psychology]: monohrafyia. Novopolotsk: PHU, 388 (in Ukrainian).

2. Berezovskaia, T. P. (2006). Osobennosty razvytyia emotsyonalnoho yntellekta starsheklassnykov [Features of high school students emotional intelligence development]. Psykholohycheskyi zhurnal, 2, 24-27 (in Russian).

3. Houlman, D. (2008) Emotsyonalnyi yntellekt [Emotional intelligence]. AST Khranytel, 10-43 (in Russian).

4. Zhuk, Yu. O. (1997). Kontseptsiia stvorennia zasobiv navchannia novoho pokolinnia dlia serednikh zakladiv osvity Ukrainy [The concept of creating a new generation of teaching aids for secondary schools in Ukraine]. Problemy osvity: nauk.metod. zbirnyk. Kyiv, 10, 207-218 (in Ukrainian).

5. Zakon Ukrainy «Pro osvitu» (2017) [About education]. Vidomosti Verkhovnoi Rady (VVR), 38-39, 380 (in Ukrainian).

6. Zarytska, V. V. (2012). Psykholohiia rozvytku emotsiinoho intelektu u systemi profesiinoi pidhotovky fakhivtsiv humanitarnoho profiliu [Psychology of emotional intelligence development in the system of professional training of specialists in the field humanities]. «Pedahohichna ta vikova psykholohiia»: dys. dokt. psykh. nauk. Zaporizhzhia, 513 p. (in Ukrainian).

7. Kreidun, N. P., Priadko, N. V. (2011). Pro deiaki psykholohichni osoblyvosti starshoklasnykiv [About some psychological features of high school students]. Visnyk Kharkivskoho natsionalnoho universytetu. Seriia «Psykholohiia», 959, 70-75 (in Ukrainian).

8. Liusyn, D. V. (2004). Sovremennыe predstavlenyia ob эmotsyonalnom yntellekte [Modern ideas about emotional intelligence.]. Sotsyalnyi yntellekt: teoryia, yzmerenye, yssledovanyia. Moskva, 29-36 (in Russian).

9. Liashch, O. P. (2015) Determinanty ta mozhlyvosti formuvannia emotsiinoho intelektu osobystosti [Determinants and opportunities for the formation of individual's emotional intelligence]. Naukovyi chasopys Natsionalnoho pedahohichnoho 
universytetu imeni M. P. Drahomanova: zb. nauk. st. M-vo osvity i nauky Ukrainy, Nats. ped. un-t im. M. P. Drahomanova. Kyiv: Vyd-vo NPU im. M. P. Drahomanova. Ser. 12: Psykholohichni nauky, 1 (46), 210-216 (in Ukrainian).

10. Mohyliasta, S. M. (2020). Prohrama rozvytku emotsiinoho intelektu starshoklasnykiv psykholoho-pedahohichnymy zasobamy [Program of developing high school students emotional intelligence by psychological and pedagogical means]. Aktualni problemy psykholohii: zb. nauk. prats Instytutu psykholohii imeni H. S. Kostiuka NAPN Ukrainy. T. I. Orhanizatsiina psykholohiia. Ekonomichna psykholohiia. Sotsialna psykholohiia, 56, 104-112 (in Ukrainian).

11. MON Ukrainy: U 26 shkolakh pochavsia pilot z vprovadzhennia prohramy rozvytku miakykh navychok SEEN: sotsialno-emotsiinoho ta etychnoho navchannia [In 26 schools the pilot on implementation of the program of soft skills development SEEN: social-emotional and ethical training has begun].https://mon.gov.ua/ua/news/u26-shkolah-pochavsya-pilot-z-vprovadzhennya-programi-rozvitku-myakih-navichokseen-socialno-emocijnogo-ta-etichnogo-navchannya (data zvernennia: 03.02.2020) (in Ukrainian).

12. Moiseniuk, N. Ye. (2001) Pedahohika [Pedagogics]. Navch. posibnyk. 3-tie vydannia, dopovnene. Kyiv, 608 p. (in Ukrainian).

13. Nazarova, T. S., Polat, E. S. (1998). Sredstva obuchenyia [Means of education]. Tekhnolohyia sozdanyia y yspolzovanyia. Moskva: Yzd-vo URAO, 204 p. Pedahohyka: ucheb. posobye (1988)/pod red. Yu. K. Babanskoho. Moskva: Prosveshchenye, 479 p. (in Russian).

14. Nosenko, E. L., Kovryha, N. V. (2003). Emotsiinyi intelekt: kontseptualizatsiia fenomenu, osnovni funktsii: monohrafiia [Emotional intelligence: conceptualization of the phenomenon, basic functions]. Kyiv: Vyshcha shkola, 67-23 (in Ukrainian).

15. Opanasiuk, I. V. (2015). Vplyv zasobiv art-terapii na rozvytok emotsiinoho intelektu starshoklasnykiv [The influence of art therapy on the development of high school students emotional intelligence]. Humanitarnyi visnyk DVNZ «PereiaslavKhmelnytskyi derzhavnyi pedahohichnyi universytet imeni Hryhoriia Skovorody». Dod. 2 do Vyp. 35, I (13): Tem. vyp. «Mizhnarodni Chelpanivski psykholoho-pedahohichni chytannia». Kyiv: Hnozys, 444 p. (in Ukrainian).

16. Orme, H. (2003). Emotsyonalnoe myshlenyia kak ynstrument dostyzhenyia uspekha [Emotional thinking as a tool for achieving success]. Moskva: KSP+, 272 p. (in Russian).

17. Petrushyn, V. Y. (2016). O razvytyy emotsyonalnoho yntellekta v protsesse muzykalnykh zaniatyi [About developing emotional intelligence in the process of music lessons]. Muzykalnoe yskusstvo y obrazovanye, 2, 68-82 (in Russian).

18. Prosina, O. V. (2018). Rozvytok emotsiinoho intelektu yak osnova formuvannia profesiinoi kompetentnosti maibutnoho vchytelia muzyky [Development of emotional intelligence as a basis for the formation of a future music teacher's professional competence]. Hirska shkola Ukrainskykh Karpat, 18, 124-128 (in Ukrainian). 
19. Rean, A. A. (2002). Psykholohyia cheloveka ot rozhdenyia do smerty [Human psychology from birth to death]. Sankt-Peterburg: Praim-Evroznak, 656 p. (in Russian).

20. Rybakova, N. A. (2015). Razvytye эmotsyonalnoho yntellekta sredstvamy muzыky. Psykholohyia y psykhotekhnyka [Development of emotional intelligence by means of music], 2 (77), 150-158 (in Russian).

21. Roberts, R. D., Mettius, Dzh., Zaidner, M., Liusin, D. V. (2011). Emotsyonalnyi yntellekt: problemy teoryy, yzmerenyia y prymenenyia na praktyke [Emotional intelligence: problems of theory, measurement and practical application]. URL: https://psy-journal.hse.ru/data/2011/04/28/1210633238/3-26.pdf (in Russian).

22. Ackerman, P. L. (1996). A theory of adult intellectual development. Process, personality, interests, and knowledge, 22, 227-257.

23. Carroll, J. B. (1993). Human cognitive abilities: A survey of factor-analytic studies. New York: Cambridge University Press

24. Gardner, H. (1993). Multiple intelligences: the theory in practice. New York: Basic Books, 304.

25. Cronbach, L. J. (1970). The essentials of psychological testing (3rd ed.). New York: Harper \& Row.

26. Mayer, J. D., Salovey, P., Caruso, D. R. (2016). The ability model of emotional intelligence: principles and updates. Emotion Review, 8(4), 290-300. URL: http://dx.doi.org/10.1177/ 1754073916639667

27. The TKT Course M1,2 and 3" (2020). Cambridge ESOL.

28. Zeinder, M., Roberts, R. D., \& Matthews, G. (2002). Can emotional intelligence (EI) be schooled? A critical review. Educational Psychologist, 37, 215-231.

Received: 16.09 .2020

Accepted: 20.10.2020 